\title{
EXPERIMENTAL STUDY ON THE EFFECT OF PENICILLIN UPON THE LABYRINTHITIS AFTER THE FENESTRATION OPERATION
}

By

\author{
K. TAKAMI
}

\section{From the Department of Oto-Rhino.Laryngoloy, Yokohama Municipal University \\ School of Medicine. (Director: Prof. T. Kasiwado)}

Based upon my statistical observations in the past on various cases of acute otitis media, I have been able to confrm that penicillin has had marked effect upon the improvement of prognosis of the disease and the prevention of its complications. Therefore $I$ have further made experimental studies about the extent of the preventive effect which penicillin might have on the post-operative labyrinthitis following to the fenestration operation of labyrinth.

The fenestration of the labyrinth have been performed on 40 rabbits. On one-half of these rabbits, 300,000 units of penicillin sol were injected into the muscules every day for one month, while the other half were left untreated. All these rabbitis were fed for one month and observations were made. Then histological specimens were obtained from their labyrinths, and histopathological examinations were carried out.

As for the reaction of the living rabbits during the time of the treatment after the operation, the rabbits which were treated by penicillin injection showed the less severe symptoms of labyrinthitis than those which were not treated. Histologicaly, while the former showed serous labyrinthitis, the latter showed purulent labyrinthitis.

The series of experiments above mentioned show that penicillin has a preventive effect in certain degrees on the post-operative labyrinthitis.

\section{開空術後性内耳炎に及ぼすぺニシリンの 影響に関する実験的研究}

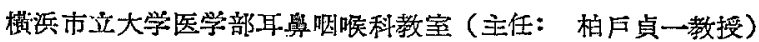

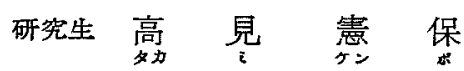

\begin{tabular}{|c|c|}
\hline & 次 \\
\hline 緈 & 諭 \\
\hline 第1幛 3 & 交献的溥案 \\
\hline 第2章 & 実驗方法及び実監材料 \\
\hline 笻了章 & 生体反忘に就いての微祭 \\
\hline 第 I 㓩 & 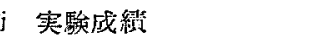 \\
\hline 筫: 2 筙 & ～総括並びに゙洘按 \\
\hline 第 $1 x$ & 珤 特発性眼球霞溜 \\
\hline 侦 $2 I$ & 项 項位の変化 \\
\hline 管了工 & 項 身体平衡障碍 \\
\hline 第 $4 \mathrm{I}$ & 项 茼創化惩 \\
\hline
\end{tabular}

\author{
第 5 项 生存期間 \\ 第 4 章 病理組織学的所見 \\ 第 1 解 非手石耳所見 \\ 第 2 䉥 手衍後無処置耳所見 \\ 等: 3 䈱 手衍後ペニシリン処置耳所見 \\ 第 4 麗 本章の総括並びに洘按 \\ 第 5 草 全䋧の䋓括並びに考按 \\ 結諭 \\ 緒論 \\ 耳科臨床においては化膿性内耳炎は重要な難症であ \\ る.しかるに近年内耳外科の進歩により，内耳に外科的
}




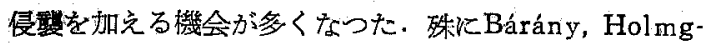
ren, Sourdille 飞始まり, Lempert 及び Schambaugh により発展した内耳開空手術の如きは非炎症性の内耳に 対しかなり大きな外科的手術を行ら・しかるに本手術発 展の糜史を見るに,その着想はすでに前世紀の末葉にあ り，当時すすで Kessel，Passow 等により試みられた に拘らず，術後に現われる内耳炎のため本問題は整く放 置せられた・しかるに今日に至って再びその手術は取り 挙げられると共に，更に一般実施に至つたのはいかなる 理由であろらか. その重要な要因は一方手術技法の改良 進频倚る所大であるが. 他方術後性内耳炎の発生予防 が容易となつたためである・即ち近年各種消炎剤の著明 な進歩があり，これによつて術徭性内耳炎はある程度防 止せられるに至つたために外ならない。しからば果して 術後性内耳炎は楽物汇よつて予防せられるであろうか.

今文献に就いて検討するに，詳細な実駼的研究は認め られない.のみならず内耳開窓術を除外しても，例えば 耳性内耳炎問題に就いても近年の薬物がこれにいかなる 程度に有効であるか，あるい恃各種耳科手術に際して棼

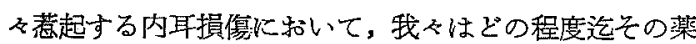
㚳に依存すべきであるか，これ等の点を知悉し置く事は 一般耳科臨床の立場に和いても重要な事である。しかる に私は嘗つて田中との共著に捣いて念性乳様突起炎の発 生に就き，教室2594 の急性中耳炎例を統計し，ぺニシ リン使用は $15 \%$ の急性乳様突起炎の 発生を $3 \%$ に迄減 退せしめた事を報告した。

就いては今回更に内耳開空術に和ける術後性内耳炎に 対し，該薬物がいかなる程度に予防効果を示すかを実駼 して聊考察を加え得るの域に達したのでこつにその成績 を報告したい，

\section{第 1 章 文献的考察}

内敢開空手術が外科的枝法の進歩と其に近年の薬物の 進歩により，大きな発展を遂げた事はすでに緒論に記し た。

しかし乍らこの種手術により惹き起される術後性内耳 炎そのものに就いての実騟的研究は比較的少い，本邦に 扔いては僅に 高原教授が Schambaugh 教授の許で猿 に就いて行つた実験の報告を見るのみである・しかし乍 ら同教授の実験炕就いて見るもその成績は単に術後性内 耳炎の病理学的分類を行つたに過ぎない。この種実験に 対し薬物がいかなる影響を及ぼすか就いては未だその 発表を見ない。しかし乍ら一方従来の交献に就いて見る に内耳開空術を離れて単なる内耳炎そのるの>実験的研
究は必ずしも㒖少ではない。

即方本邦灿いて子中村 (登), 田中, 小田, 藤森 (真 治), 鳥居, 永井・篠田等古〈は Schötz, Herzog, Haymann, Brau 等諸家により広汎な研究が行われてい る.

今その内耳の催炎方法を列記すれば

1.クロロホルムその他有機化合物を外耳道内に 注 入; 田中，小田.

2. 中耳胞を開放してホルマリン，三塩化醋酸，クロ ム酸等をむつて内部を詹蝕; Schötz.

3. 中耳を開文正円空第 2 鼓膜を通じて 細菌あるいは トキシンを内耳内に注入；Brau。

4. 中耳胞を開き正円空に栓塞を施し，あるいは化学 的物質を空内に入れその上を栓塞; Herzog.

5. 外耳道より鼓償を穿刺し細菌あるいはトキシンを 中耳腔内に注入；中村.

6. 蛤牛殼, 正円空, 半規管を露出し, 淁壁を腐䶿又 は穿開; 藤森.

7. 予め鼓膜を穿刺して鼓室内に細菌浮游液を注入し て中耳炎を起さしぬ頭部叮打を行う；篠田.

等がある・しかし乍らこれ等諸家の研究はすべて中耳 腔丁至内耳内に特殊の起炎物質を插入乃至感染せしぬ, その結果起るところの内耳炎に就その感染経路, 病理 組織学的変化を追究したに止る・しかるに最近教室の山 岸は内耳開空術の研究に和いて家東を用い，充分なる消 毒の下に外科手術を行い爾後その創腔の動物生体に及ぼ す反応を検討すると共に，一定期間の後，生体固定を施 しその内耳の病理組織学的变化を追究した．しかる所充 分隇菌的配感を行つたに拘らずなお一部動物には術後性 内耳炎の発生を見，この種の実駼㶤括いては抗生剂乃至 スルフォンアミド鼡を使用したならば更にある程度迄こ の種内耳炎の発生を予防し得たであるうという事を記述 した・よつて私は山岸のこの推論従い実験を進める事 とした、私の実験方法並びに材料は炊の如くである.

\section{第 2 章 実験方法及び実験材料}

当教室山岸の研究に做い，体重 $2 \mathrm{~kg}$ 前後の成熟家鬼 にて外耳道, 鼓膜, 頭位, 体位に異常なく、プライェル 反射正常，運動障碍を認めぬるのを選び，ウレタン麻醇 の下にこれを腹位固定し，耳周团を脱毛し，外耳道治 滌を行つた後, 沃度丁幾叙布, 次いでアルニールにて充 分清掝し，耳翼附着部後方に皮膚切開を加克，軟部外耳 道, 骨部外耳道接合部を切離し，骨部外耳道外側部盤開 により上鼓室简を開放しこつに透見する水平半規管に 
酰科用電気エン、ジンバーにて小孔を作り，外淋巴腔を開

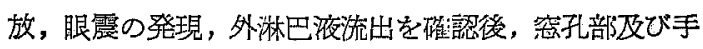
術野を生理的食塩水にて洗临し，その部沉 $1 \%$ マーキニ ロクロム液を塗布し，軟部組織を一次的に紱合し術を了

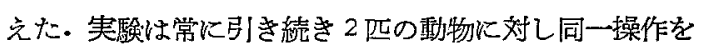
行い, 爾後飼養箱内に飼盖したのであるが,この間一匹

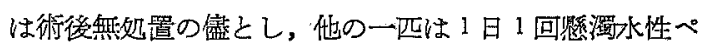
ニシリン G 30 万単位を30日間連続腰笳に注射し，肃 戨粉数 40 匹に至つた. 又その間実験動物に就いては連 日その生体反応を観察した。

次いでこれら動物を血滩隻流によりその内耳を生体固 定した. 不幸にして実娩中に死亡したものは死後固定を 行つたが，死後動物といえどむ可及的死後变化を避ける

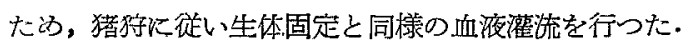
しふる後鯰器を分離，中耳胞を開放し，ウイットマーク 民液に 14 日間浸清し，後固定を行つた。固定後硝酸木 ルマリンにて 10 日間脱灰し，5\%硫酸ッーダにて 12 時

第1表（その1）生体反応穓察成績

生存日数は 1 力月以丙に死亡せるるるの了み管载

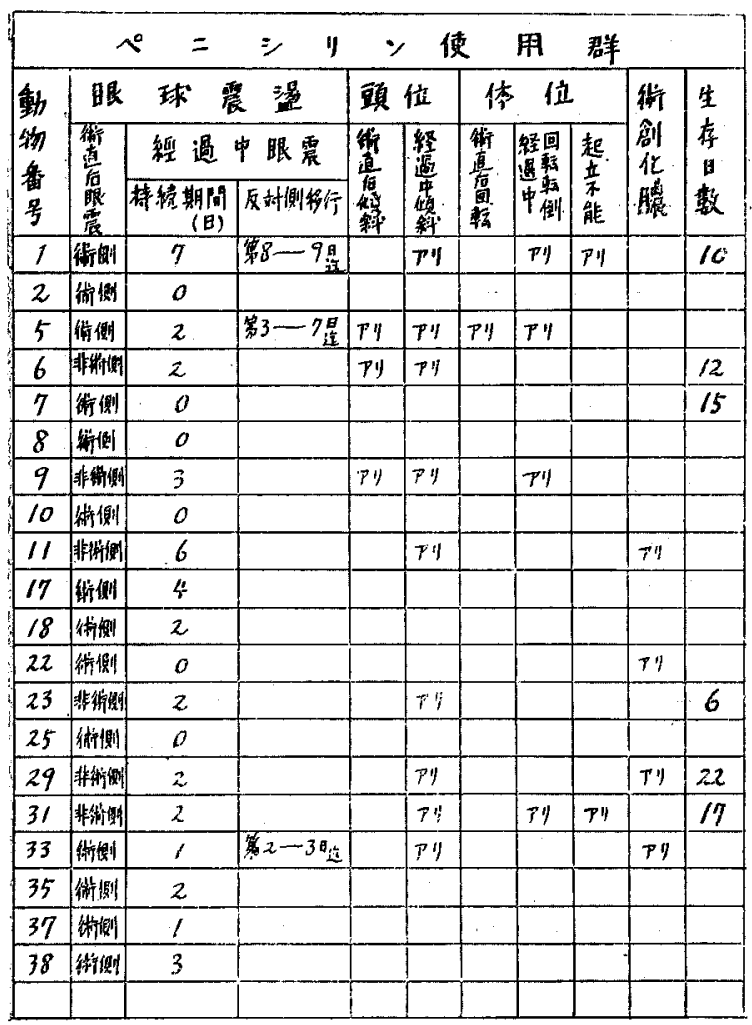

間中和，次いで水洗，脱水，エーテルアルュール等分灌， を経て後 2〜4〜8\%ッェロイジン液に充分浸清包埋を行、 つた・次いで $20 \mu$ の連続切片を作製しへマトキシす ン・エオジン重染色を行い鏡検した。

\section{第 3 章 生体反応に就いての観察}

第 1 節 実験成結

実娩方法汇記戴した如く動物は手術中，手術直後及ひ： 爾後 30 日連続観察し, その生体反応に注意した.

最初型の如く開空手術を行引に水平半規筸”骨壁をバー をもつて削つて行くに，外淋巴腔開放の行われぬ中は動 物には著明の反応は無い，丁度骨壁を削り外淋巴胵に空 孔が作製されたと思われる時沉初めて都明の反応が見ら れる・先づ第一に局部より外淋巴液の流出を認める. 同 時比特発性眼球震洫の出現を認める. 更に手術を完了し 動物を固定台より解放する㭙は頭位の変化，乃至身体平 衡障碍をきたし回䎐運動を行い，起立不能となり転倒す る場合もあつた。これ等の所見は動物により区ふであつ

第1表（その2）生体反応穓察成績

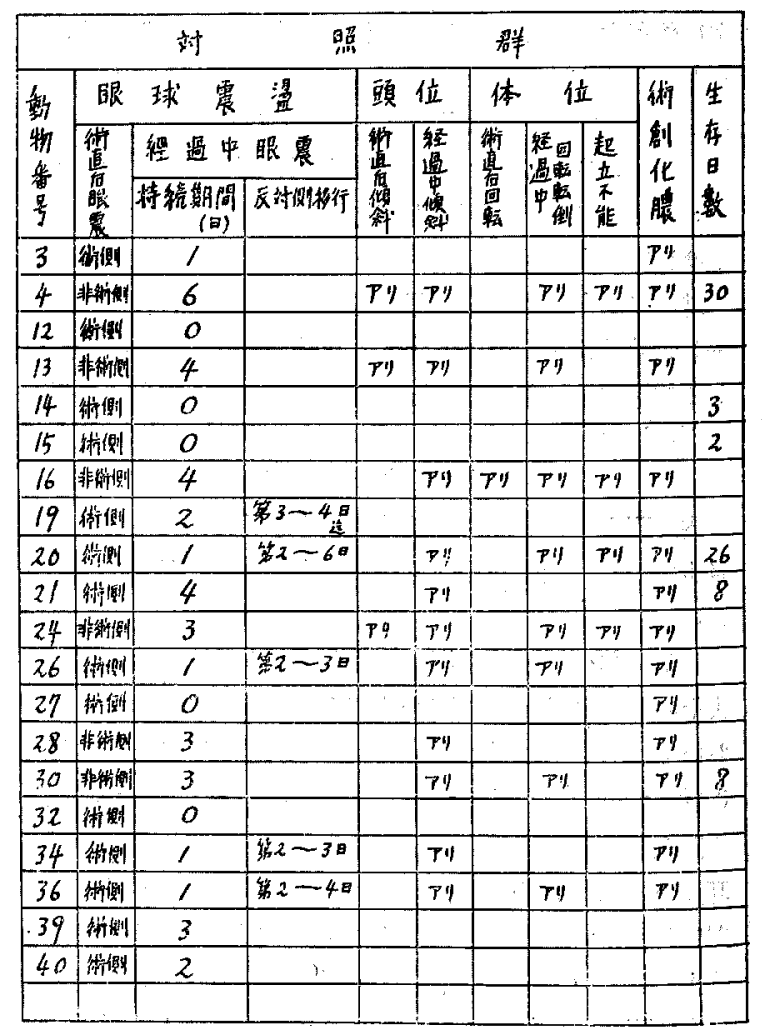


たが，眼球震燙を除いては他の障碍は手術值後には滦め て少数であつた・しかし乍ら連日飼盖し，観察して和る "柽過中炕これ等の症比が現われてきたるのるあつた。 夹等筧察專項に就き各動物に認められた所を表示すれ 壮第1表（その1）及び（その2）となる. なおこれ等各症状の詳細の模栐は炊のようである。

\section{第 1 項 特発性眼球震燙}

A. 術中及び術直後眼震

1. 開空成功と同時に細小頻数で術側に向う水平性の 眼震が起り同時に頭震璗を伴い，徐々に緩徐な眼震比移 行し, 約 20 分後に消失したもの.

2. 術直後眼震が消失せず持続性に術側に向ら眼震を 惩めたもの:

3. 術直後直ちに非術側に向う中等大腿震の 発現した もの，且つこの場合は殆んど同方向眼震が持続性であつ た.

以上の 3 種を観察した.

B. 術後経過中眼震

術後第 2 日目以後に 認められた眼震は次の如くであ る.

1. 体動時術側方向の眼震が認められたが炊第に消失 したもの.

2. 初めより非術側に向う眼震の持続したもの.

3. 初め術側方向であつた眼震が経過途中より非術側 に移行したもの.

以上の 3 種があつた。

第 2 項 頭位の変化

1. 開空するや直ちに眼震と同時に鼻尖を非術側に向 け，後左右に振子栐運動を反覆するも，間もなく消失し 上後頭位に変化なきす。.

2. 術直後直ちに頸部を捻鞋術側傾斜の起つたもの.

3. 経過中術側傾斜の起つたるの.

以上 3 種があった。

第 3 項 身体平衡障碍

1. 何等の身体平衡障碍を認めぬるの.

2. 郝後経過中に術側に迴転々倒を起したもの.

3. 術後直ちに迴転々倒を起したもの.

4. 全く起立不能とならたもの.

以上 4 種があった。

第 4 項 術創化膿

1. 経過観察中に手術創特に耳後縫合部及び 外耳道に 㬴汗を認めたるの，あるいは断頭時，中耳胞内に膿汁文 は壊死物を認めたもの.
2. 全く変化なく清浄なるの.

以上の 2 種を区別した。

第 5 項 生存期間

以上の動物は総て手術後 1 カ月間の飼盖観察を心掛け たのであるが，一部の動物は1 月以内に死亡した。

第 2 節 総括並びに考按

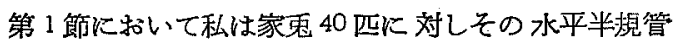
に開空操作を行い，その半数に30日間連日暞濁水性ぺ ニシリンG 30 万単位の䄈肉注射を行い，その半数は 無処置の儘とし，その生体反応を観察したが，本節に和 いてはその成績を基整とし一つの考察を行う。

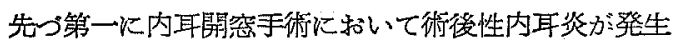
するか否やに就いては改めてこれを論ずる必要な無い。

唯こつで問題とせられる所は高原，高久等が述べて括 る如く，開空操作关のるのによって内耳炎発生の度合は 多少相違する・即ち内取に対し大きな外科的衝整を与え るか否かによってその後の反応にはある程度の美異を起 す.これがため私は総ての動物に対し努めて同程度の開 窓を行ら事を心掛けた・しかし乍ら外科操作が常に完全 に同一である事性困難である。

よつてその程度を見るに，先づ手術中又は手術直後に 見られた動物の特発性眼球震湓，頭位变化又は身体平衡 障碍発現の模様を第 1 表に就き考察し、ペニシリン使用 群と対照群と比較するに，第 2表のようである。

第 2 表 衍吤乃至衍㨁後特発性眼霞, 頭位资化,

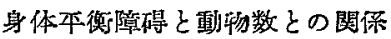

\begin{tabular}{|c|c|c|c|}
\hline & & 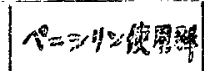 & 劫照瑟 \\
\hline \multirow{2}{*}{$\begin{array}{l}\text { 特的 } \\
\text { 的 } \\
\text { 住 }\end{array}$} & 街排出现 & 14 & 14 \\
\hline & 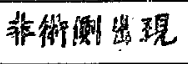 & 6 & 6 \\
\hline \multicolumn{2}{|c|}{ 頭值倾科 } & 3 & 3 \\
\hline \multicolumn{2}{|c|}{ 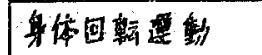 } & 1 & 1 \\
\hline
\end{tabular}

今第 2 表を見るに術中乃至術直後に見られた内耳刺激 の度合は各動物によつて必ずしも同一でない.しかし乍 らペニシリン使用群と非使用群とにおいて種々なる度合 の手術の行われた頻度を比較すると両群に㨟いてほぶ同 様である。

開空操作により特発性腿震の発現する模様は高久の実 験的研究に上れば水平半規管の脚部汲び膨大部，並びに 窓孔の大小, 又は局部出血等種々の因子によつて決定せ 
られるといら事であるが，以上の成績より私の実験にお いては実験並びに対照群に执いてほぶ同一条件にあつた と考えられる・しかるに今第 1 表比就いて手術後の経過 に括いて認められた症状を比較すると，必ずしもぺニシ

リン使用群と対照群とでは同一でない。

各症状を項を別つて観察するに次の如くになる。

第 1 項 特発性眼球震湯

先つ’手術中又はは手術淔後に認められた特発性眼球震 湯の持続日数を見るに，第 3 表のようである。

第 3 表 手衍守乃至手衍值後䚁察されざ特発性 眼球震盓の持続日数々鼠物数との関保

\begin{tabular}{|c|c|c|}
\hline 持続㔭 & ペ使用群 & 齐照群 \\
\hline 0 & 6 & 5 \\
\hline 1 & 2 & 5 \\
\hline 2 & 7 & 2 \\
\hline 3 & 2 & 4 \\
\hline 4 & 1 & 3 \\
\hline 5 & & \\
\hline 6 & 1 & 1 \\
\hline 7 & 1 & \\
\hline
\end{tabular}

この成績によれば必ずしも手術によつて惹起された特 発泩眼球震鳁の消長にペニシリンが影響を与えて括る上 は考员られない，しかるにその後の経過飞怙いて見られ た眠球震蕰の性質の变化を見るに，術後引続いて存在し た眠球震燙がその力向を变更した例数はぺニシリン便用 群 3 例 (No1，5，33) であるに対し，対热群は6 例 (No. $19 ， 20 ， 21 ， 26 ， 34 ， 36)$ である. その持続日数はいら゙れ も 2 万至数日に止つたが，この吾は手術後経過に招いて 内耳の変性が実駿群よりも対照群に强かつた事を示すも のである。

第 2 項 頭位の变化

頭位変化の術直後出現率は実験並びに対照群同数であ つた。しかし乍ら術後の経過に执いて改めて頭位変化 の出現したものは，ペニシシン使用群にあつては6例 (No.1，11，23，29，31，33) 対照群にあつては8 例 (No. $16,20,21,26,28,30,34,36)$ であつてこの点経過中
特登:性眼球震逿の性質変更の場合と同様対弨群において ペニシリン使用群よりも頻度が高い。

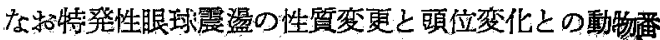
号の一致を見るに，ペニシリン使用群にあつては特発性 眼冰震蕰方向变化の 3 例中 2 例，対照群にあつては 6 例 中 5 例迄は一致していた。

\section{第 3 項 身体平衡障䅞}

身体平衡障碍に就いては手術直後身体回転を示したる のは両群とも僅かに 1 例であつたが，経過と共にこの症 状の出現したものはペニシリン 使用群 3 例（No.1，9， 31）であつたが，対照群 7 例（No.4，13，20，24，26，30， 36）であつた。本症状は内耳刺激による強迫姿勢である が，本症状と眼球祳盪乃至頭位変化との一致度を見るに 第 4 表のようである.本表に就いて見れば手術後経過に 扎いて内耳次第に病変が現れてきた模樣はぺニシリン 使用郡に比し対照群においてより顕著であつた。

第 4 表

\begin{tabular}{|c|c|c|}
\hline & $ヘ^{\circ}=シ ク=$ 使用群 & 对 照 群 \\
\hline (1) 眼球'票量方向变更 & & / (No. 19) \\
\hline (z) 頭位李化 & $4(N 0.6,11,23,29)$ & $/(N 0.28)$ \\
\hline \multicolumn{3}{|l|}{ (3)身体平衡障碍 } \\
\hline (4) $(1)+(2)$ & $1(\mathrm{No}, 33)$ & $3(\mathrm{~N} 0.21,34,36)$ \\
\hline (5) $(1)+(3)$ & & \\
\hline (6) (2) $+(3)$ & $2($ No. 9.31$)$ & $5\left(N_{0}, 4,13,16,24,30\right)$ \\
\hline (7) $(1)+(2)+(3)$ & $2(\mathrm{No} .1,5)$ & $3\left(N_{0.20}, 26,36\right)$ \\
\hline
\end{tabular}

第 4 項 術創化膿

以上内耳淀状の術後変化はぺニジリン使用群よりる対 昭群に执いてより顕著であつたが，これを術創化膿の面 より見るにペニシリン使用群は術創化膿を起したすのは 総数 4 例 (No.11，22，29，33）に過ぎないが，対照群似 あつては総数 13 例（No.3，4，13，16，20，21，24，26， $27 ， 28 ， 30 ， 34 ， 36)$ に及九だ. 而してこれ等症例の第 4 表に揭げらた症例との一致度を見るにぺニミリン倞用君 は No.22 対招群は No.3 及び No.27 の3 例を除いて 他は総て一致している。この点上り考察すれば手待後に おける内耳変性と術創化滕との間にはかなりの関采があ つたるのと想像せられる。

第 5 項 生存期間

生存期間に就いては第 1 表より実龭完了前に死亡した 実数は両群之る同数で西つた.従つてベニシリン使用の 有亜が動物生存日数に迄影響を及ばしたとは考えられな 
?.

\section{第4章 病理組䌙学的所見}

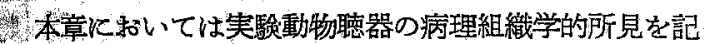
载さる。陲物番号 1，2，10，14，15，27 は組織標本を作 製する事がでさなかつたが，他は総てこれを作つた。標 本作製直前の生死の模栚及びこの間の処置を 1 表とすれ は第 5 表の如くである. 以上の標本は次の 3 群に別けら れる。

第 5 表 家鬼丙耳固定時の状散

\begin{tabular}{|c|c|c|c|c|}
\hline $\begin{array}{c}\text { 実験動物 } \\
\text { ，番 号 }\end{array}$ & 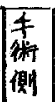 & $\begin{array}{l}\text { 固定時生死 } \\
\text { の狀㴰 }\end{array}$ & 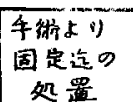 & 㒂率 \\
\hline 3 & 左 & $\overline{\bar{b}}$ & 7 & \\
\hline 4 & $"$ & $\bar{r}$ & " & \\
\hline 5 & " & 生 & 今佒用 & 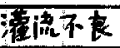 \\
\hline 6 & 11 & 㘸 & " & \\
\hline 7 & $\pi$ & " & 4 & \\
\hline 8 & $n$ & 生 & " & \\
\hline 9 & $"$ & II & $\pi$ & \\
\hline 11 & $t_{a}$ & 死 & $"$ & \\
\hline 12 & $"$ & 生 & 艋。 & \\
\hline 13 & $" 1$ & i & " & 港搔子良 \\
\hline 16 & $\sqrt{2}$ & EE & in & \\
\hline 17 & 11 & 4 & 人续用 & \\
\hline 18 & $"$ & 生 & $" \prime$ & \\
\hline 19 & $"$ & " & 䉑. & \\
\hline 20 & $\because$ & $\overline{\text { se }}$ & " & \\
\hline 21 & $"$ & $n$ & $"$ & \\
\hline 22 & " & 生 & 八保用 & \\
\hline 23 & "' & 开 & $"$ & \\
\hline 24 & $"$ & 坐 & 镡 & \\
\hline 25 & " & "1 & 便用 & \\
\hline 26 & $"$ & $\bar{F}$ & te & \\
\hline 28 & $"$ & 生 & 1 & 灌罱不良 \\
\hline 29 & $" 1$ & 死 & 入传用 & \\
\hline 30 & $"$ & 4 & 重. & \\
\hline 31 & " & 生 & 虽用 & \\
\hline 32 & $"$ & " & 墨 & \\
\hline 33 & " & 11 & ペ使用 & \\
\hline 34 & $\approx$ & 死 & h. & \\
\hline 35 & $"$ & 生 & N促量 & \\
\hline 36 & $\because$ & 死 & 篮. & \\
\hline 37 & $"$ & 生 & 人传用 & \\
\hline 38 & " & " & $"$ & \\
\hline 39 & 右 & 死 & 縏。 & \\
\hline 40 & " & 生 & 1 & \\
\hline
\end{tabular}

（1）非手術側耳，(2) 手術後無処置耳，(3) 手術後ぺ ニシリン边置耳.

よって以上の 3 項に從い，その所見を記述する。

第 1 節 非手術側耳所見

実験は多くは一側耳に就いて行われた。従つて他側は 非手術耳に相当する・乙かし乍ら内耳の病理組織学的検 索に当つては単に実駼耳のみに就いて桧索を行つたので は時汇実験上の譟差を招くこれは生体固定時操作，死 後変化，標本作製影変形等が影響するためである・よつ て私は先づ非手術耳に就いて検討した。私が非手術耳に 就いて 標本を作邫し 得たものは No.5, 16, 17，18，19. $20,21,22,23,24,26,27,28,29,31,32,34,36,37$, 38,39 の計 21 耳である.

今夫等内耳に就き認め得た所見を生体固定を行い得た あの及び死後固定を行つたるのに別け，夫々1表とす机 ば第 6 及び第 7 表となる. 今第 6 及び第 7 表を比較する に一般に生体固定例に比し死後断頍固定例は内耳各成分 に多少変化の增強を見たが，その主とする所は淋巴腔内 雲絮状物質睁溜, 硝子樣物質充填, ティスネル氏㨫变 化，各神経上皮の蘶缩あるいは膨化等であって，その他 の多くの例は両群共汪ら゙正常であつた。

策 2 節 手術後無処置耳所見

水平半規管让箅空を行い，しかる後度虐創を縫合し， その儘何等の奶置を加兄ず，飼養観察し，手術後 1 ケ月 以上飞至り，生体固定を行つた動物の内耳所見は第 8 表，手術後 1 ケ月間生存し得ずその以前に扣いて死後断 頭固定の止むなきに至つた動物及び 1 ケ月以上生存した が生体固定不能であつたもの>内耳所見は第 9 表の如く で, 前者は総数 7 例 $(\mathrm{No} .12,13,19,24,28,32,40$ ) 後 省は総数 10 例 (No.3，4，16，20，21，26，30，34，36，39） である。

今第 8 並びに第 9 表を見るに総数 17 例において開密 倽を明暸に認得たものは No.3, 21，24, 30 の 4 例で， No.4 攵び 26 は鐙骨脱臼を認め，他の 11 例は創孔が明 瞭でない.この事は不幸にして標本上にその創孔を捉え 得なかつたか，あるいは時間の経過と共に創孔が閉鎖乙

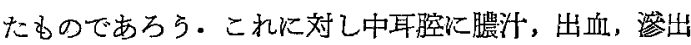
物，結締織を認めたものはNo.4，13，16，20，21，24， 26，28，30，32，34の11例であつた.これに対し内耳に 著明の变化を認めたものは No.4，16，21，24，26，30,34 の7 例でその所見は内耳腔内膿汗充满, 結締織增殖, 漻 出物貯溜，内耳組織成分の破壊等であつて，これ等は非 手術耳には全く認められぬ所であり，その所見の分布の 
第 6 表 非手街耳所見（生体固定瞕）

\begin{tabular}{|c|c|c|c|c|c|c|c|c|c|c|c|c|}
\hline$A_{4}$ & $t$ & 75 & 前 & & 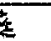 & 螅 & 4 & th & & 水 & 要半 & 管 \\
\hline 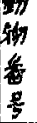 & 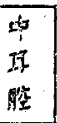 & 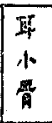 & 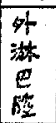 & 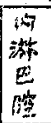 & 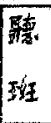 & $\begin{array}{l}\text { 前 } \\
\text { 乿 } \\
\text { 階 }\end{array}$ & $\begin{array}{l}\text { 鼓 } \\
\text { 室. } \\
\text { 紫 }\end{array}$ & $\begin{array}{c}\text { 蝙 } \\
\text { 特 } \\
\text { 熟 } \\
\text { 管 }\end{array}$ & 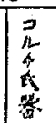 & 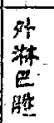 & 离 & $\begin{array}{l}\text { 㯖 } \\
\text { 䑨 }\end{array}$ \\
\hline 5 & & & & 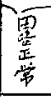 & & & & 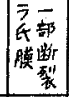 & & 量 & & \\
\hline $1 / 8$ & 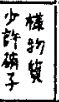 & & $\begin{array}{l}\text { 畧 } \\
\text { 等 }\end{array}$ & & & 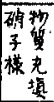 & & $\begin{array}{l}\text { 芯舉 } \\
\end{array}$ & 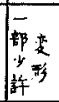 & & 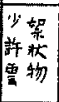 & \\
\hline 19 & 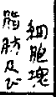 & & & & & 毁 & & & & & & \\
\hline 22 & & & & & & 䨝 & & & & & & \\
\hline 24 & & & & & & 罿 & & & & & & \\
\hline 27 & -1 & & & & & 整 & & & & & & \\
\hline 28 & & & 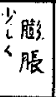 & & 容 & & & 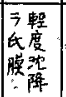 & 変变 & 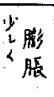 & & \\
\hline $3 /$ & 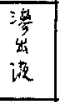 & & & 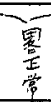 & & & & 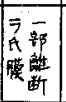 & $\begin{array}{l}\text { 少秦 } \\
\text { 稆 }\end{array}$ & $=$ & 重 & \\
\hline 32 & & & & & & 暸 & & & & & & \\
\hline 37 & & & & & & 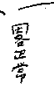 & & . & - & & & \\
\hline 38 & & & & & & $\begin{array}{l}\frac{1}{3} \\
\frac{2}{2} \\
\frac{5}{6} \\
\end{array}$ & & & & & & 短 \\
\hline
\end{tabular}

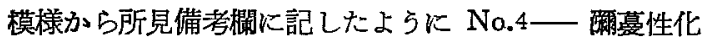
膿性内耳炎，No.16，21，26一限局性化膿性内耳炎， No.24, 30 一化骨性万至増殖性万至限局性化膿性内耳 炎，No.34一踏液性内耳炎と判定された.

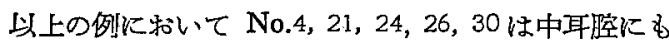
著明な炎症あり，鐙骨脱臼乃至開空孔明瞭である故，こ の部を通じ中耳腔の炎症が内耳に波及したものと想像さ れる・No.3のみは創孔明瞭であつたが内耳炎所見なく， 多数例中にはこの種の経過もあり得ることを示して拉 る. No.16 奴び34の内耳资がいかたして発生したか， 標本に特いては開空孔は明瞭でなかつたが同じく開空部 よりの感染であろらを想像される.

第3節 手術後ペニシリン処置耳所見

手術実施後 1 カ月間每日泪漫水性ペニシリン G 30 万
第 7 表 非手彷耳所見（死後固定群）

\begin{tabular}{|c|c|c|c|c|c|c|c|c|c|c|c|c|}
\hline \multirow{2}{*}{$\begin{array}{l}\text { 龁 } \\
\text { 物 } \\
\text { 告 } \\
\frac{5}{5}\end{array}$} & \multicolumn{2}{|c|}{ 中 7} & \multicolumn{3}{|c|}{ 前 庭 } & \multicolumn{4}{|c|}{ 蛤 牛款 } & \multicolumn{3}{|c|}{ 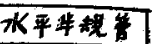 } \\
\hline & $\begin{array}{l}\text { 中 } \\
\text { 耳 } \\
\text { 臊 }\end{array}$ & $\begin{array}{l}\text { 耳 } \\
\text { 小 } \\
\text { 蓇 }\end{array}$ & 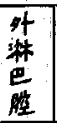 & 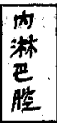 & $\begin{array}{l}\text { 㤮 } \\
\text { 班 }\end{array}$ & $\begin{array}{l}\text { 前 } \\
\text { 庭 } \\
\text { 陼 }\end{array}$ & $\begin{array}{l}\text { 教 } \\
\text { 室 } \\
\text { 階 }\end{array}$ & 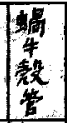 & $\begin{array}{l}7 \\
\frac{1}{2} \\
4 \\
k\end{array}$ & $\begin{array}{l}\text { 舛 } \\
\text { 梠 } \\
\text { 辇 }\end{array}$ & 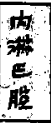 & \\
\hline 16 & & & 㭾 & 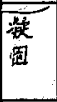 & $\begin{array}{l}\text { 部 } \\
\text { 影 } \\
\text { 離 }\end{array}$ & & 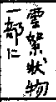 & 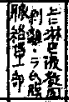 & $\begin{array}{l}\text { 部 } \\
\text { 弯 } \\
x_{3}\end{array}$ & & & \\
\hline 17 & & & & 畧 & & & $\begin{array}{l}y \\
y \\
\text { 热 } \\
\text { 蓝 }\end{array}$ & & & 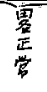 & & re \\
\hline 20 & & & 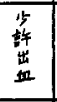 & 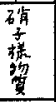 & . & $\begin{array}{l}\bar{y} \\
\text { 部 } \\
\text { 变 } \\
\end{array}$ & 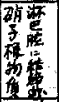 & & & 㟟 & & \\
\hline$|2|$ & - & & 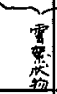 & & & & & & $\begin{array}{l}y \\
5 \\
5 \\
\text { 委 } \\
\text { 形 } \\
\end{array}$ & & 5 & \\
\hline 23 & & & & & & 竟 & & & & & 3 & \\
\hline 26 & & & $\begin{array}{c}\text { 妾 } \\
\text { 形 }\end{array}$ & & 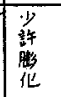 & & & 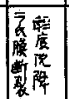 & 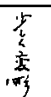 & & & \\
\hline 29 & & & & 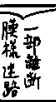 & 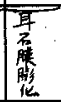 & & & 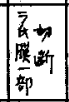 & & & 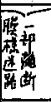 & 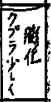 \\
\hline 34 & & & & $\begin{array}{l}\text { 霎 } \\
\frac{2}{7}\end{array}$ & & & & & $\begin{array}{r}\text { 部路 } \\
\text { 化 }\end{array}$ & & & \\
\hline 36 & & & & 罯 & & & & 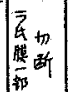 & $\begin{array}{l}\text { 菨 } \\
\text { 維 }\end{array}$ & $\begin{array}{l}\text { 得 } \\
\text { 脤 }\end{array}$ & & \\
\hline 3 & & & & & 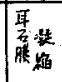 & & & 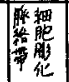 & $\begin{array}{l}\text { 蒵 } \\
\text { 維 }\end{array}$ & $\begin{array}{l}\text { 缩 } \\
\text { 少 }\end{array}$ & & \\
\hline
\end{tabular}

単位の筋冬注射を行つた動物の耳所見を前節と同様生体 固定及び死挠固定に別ち夫々 1 表とすれば第 10,11 表の よ5になる・即ら生㑂固定群は舅No.5，8，9，18，22，25， $31,33,35,37,38$ の 11 例, 死後固定群は No.6, 7, 11, $17,23,29$ の6例である.

今第 10,11 表に就いて見れば水平半規管の開空部加明 瞭であるのは No.6, 7, 9, 11, 17, 35 で他の例は不明 である・これに対し中耳胵に炎症所見を示したものは No.6, 7, 9, 11, 17, 22, 23, 29, 31, 33, 35 である. 即ら

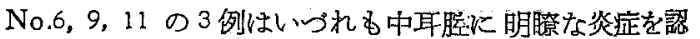
め, 同時に開空部子結締織增殖，骨再生乃至増殖，出 物万至出血，又は骨性閉鎖を示したが，これ等症例は夫

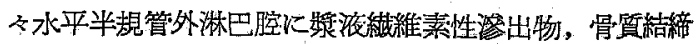
織，淋巴球等の所見を認め，又は内淋巴腔又は前庭，蝸

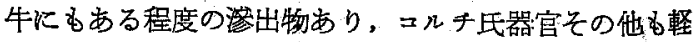
微の病変方あつて, いうれれ主として限局性獎液性内耳 
第 8 表 手微後些迈置耳所見（生体国定群）

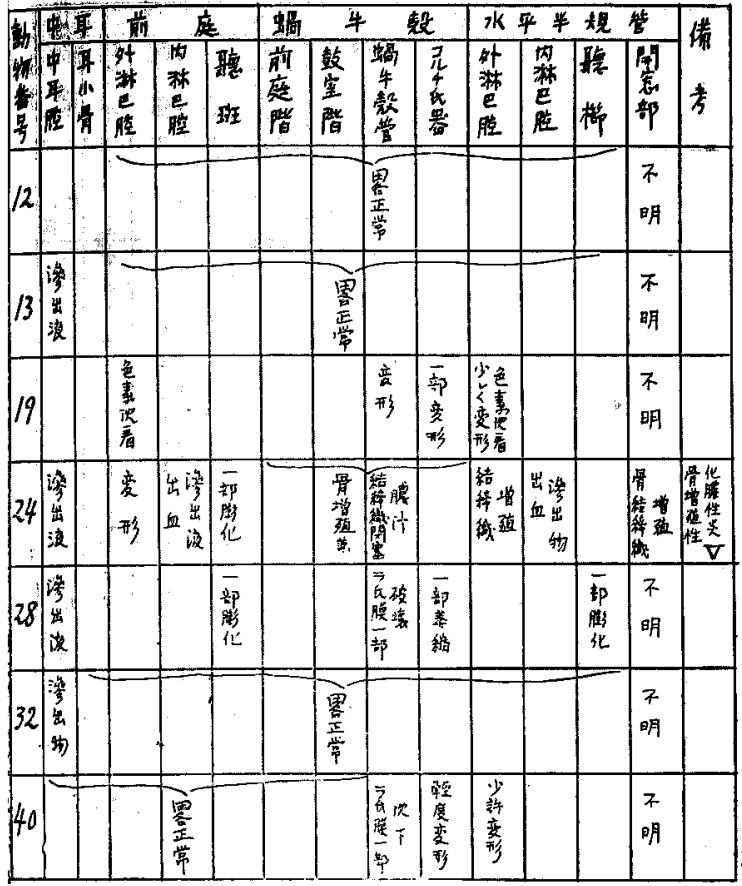

桨の像を認めたが，No.35 のみは中耳腔の病変にも拘 らず内耳活5゙正常であつて，この他 No.23，29，31，33 は摽本上開空部を明確にし得なかつたが，内耷殊に水平 半規管外淋巴堙に出物, 出血, 血管充血, 結締織堌加 を認め,これに応し前庭, 蝸牛にも軽微の変形を認めし めた点上り街後性㝥液性内耳炎を思わしめた。

結局本群にあつては No,6，9，11，23，29，31，33 を夫

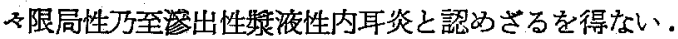

残り No.5, 8, 18,22, 25, 35, 37, 38 の8例はいつうれ 6開空部不明，7，17，22，35 の 4 例除いては中耳胵に も炎症無く，内耳自身す活じ正常である程度の手術的損 傷は加えられたけれどもその後の経過非常に良好な例で ある.

\section{第 4 節 本章の総括並びに考按}

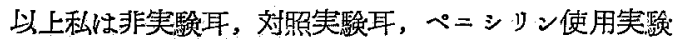
耳に就き各節に別つてその所見を記載したが，本節にお いてはこれ等総てを一括して考按する。

先つ第一に非実験耳に就いては 21 耳を通じ，その大 部分が活よ゙正常内耳所見を示した。唯その一部沉多少の 異常所見を認めたが，これ等は実験の性質上死後変化乃. 至標本作製時变化と見做される・従つてこの種の变化を

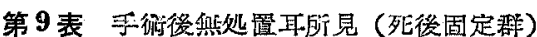

\begin{tabular}{|c|c|c|c|c|c|c|c|c|c|c|c|c|c|c|}
\hline \multirow{2}{*}{ 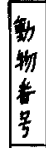 } & \multicolumn{2}{|c|}{ 中耳 } & \multicolumn{2}{|l|}{ 前 } & 庭 & \multicolumn{2}{|l|}{ 蝙 } & \multicolumn{2}{|c|}{ 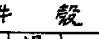 } & \multicolumn{4}{|c|}{ 永 } & \multirow{2}{*}{ - } \\
\hline & \begin{tabular}{|l|} 
中 \\
7 \\
㓌 \\
\end{tabular} & \begin{tabular}{|l|} 
耳 \\
$11 \cdot$ \\
$\operatorname{h}$ \\
\end{tabular} & 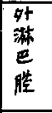 & \begin{tabular}{|l|} 
菻 \\
落 \\
\end{tabular} & $\begin{array}{l}\text { 譩 } \\
\text { 斑 }\end{array}$ & $\begin{array}{l}\text { 前 } \\
\text { 庭 } \\
\text { 階 }\end{array}$ & 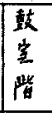 & 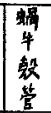 & 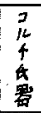 & 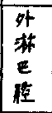 & \begin{tabular}{|l|} 
内 \\
淋 \\
$E$ \\
跬 \\
\end{tabular} & 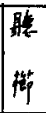 & $\begin{array}{l}\text { P } \\
\text { 晏 } \\
\text { 部 }\end{array}$ & \\
\hline 3 & & & & & 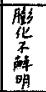 & & & 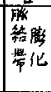 & 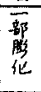 & 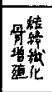 & & & 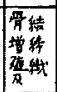 & \\
\hline 4 & $\begin{array}{l}\text { 劈 } \\
\text { 出 } \\
\text { 出 }\end{array}$ & 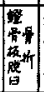 & 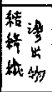 & 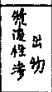 & 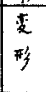 & 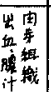 & $\begin{array}{l}\text { 腰 } \\
\text { i十 }\end{array}$ & 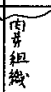 & $\begin{array}{l}\text { 消 } \\
\text { 失 }\end{array}$ & 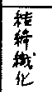 & 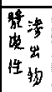 & 变 & $\begin{array}{l}7 \\
\text { 明 }\end{array}$ & 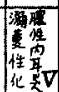 \\
\hline 16 & 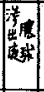 & & 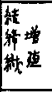 & 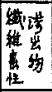 & $\begin{array}{l}\text { 成 } \\
\text { 化 }\end{array}$ & $\begin{array}{l}\text { 出 } \\
\text { 血 }\end{array}$ & 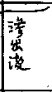 & 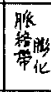 & $\begin{array}{l}\text { 影 } \\
\text { 化 }\end{array}$ & $\begin{array}{l}\text { 出漊 } \\
\text { 血 }\end{array}$ & 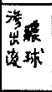 & \begin{tabular}{|l} 
\\
弯
\end{tabular} & $\begin{array}{l}\text { 不 } \\
\text { 明 }\end{array}$ & 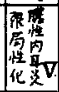 \\
\hline 20 & & & & & & 䀩 & & & 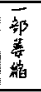 & & $\begin{array}{l}\bar{z} \\
\text { 常 }\end{array}$ & & $\begin{array}{l}7 \\
\text { 明 }\end{array}$ & \\
\hline 21 & 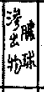 & & $\begin{array}{l}\text { 理 } \\
\text { 球 }\end{array}$ & 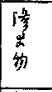 & & 晠 & & $\begin{array}{l}\text { 淁 } \\
4 \\
4 \\
\text { 范 }\end{array}$ & 砇 & 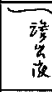 & & & 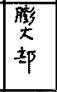 & 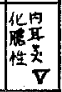 \\
\hline 26 & 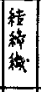 & 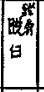 & \begin{tabular}{|l|}
$3 \frac{3}{5}$ \\
出 \\
场
\end{tabular} & 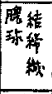 & \begin{tabular}{|l} 
破 \\
丧
\end{tabular} & 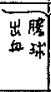 & 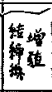 & 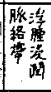 & 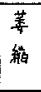 & & & \begin{tabular}{|l|} 
膨 \\
化
\end{tabular} & $\begin{array}{l}\text { 不 } \\
\text { 明 }\end{array}$ & 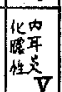 \\
\hline 30 & 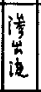 & & & \begin{tabular}{|l|}
5 \\
出 \\
物
\end{tabular} & & & 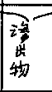 & & 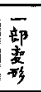 & & & $\begin{array}{l}\text { 破 } \\
\text { 境 }\end{array}$ & 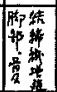 & 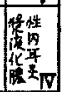 \\
\hline 34 & \begin{tabular}{|l|} 
清 \\
出 \\
物
\end{tabular} & & & \begin{tabular}{|l|} 
涪 \\
出 \\
做 \\
\end{tabular} & 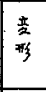 & & & \begin{tabular}{|c|}
$\frac{4}{3}$ \\
4 \\
4 \\
淡 \\
\end{tabular} & $\begin{array}{l}\text { 宷 } \\
\text { 絈 }\end{array}$ & & & & $\begin{array}{l}\pi \\
2 \\
\text { a }\end{array}$ & 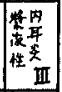 \\
\hline 36 & & & & & & & & 褰 & & & & & $\begin{array}{l}7 \\
\text { 明 }\end{array}$ & \\
\hline 39 & & & & & & & & 正里 & & & & & \begin{tabular}{|c|} 
\\
明
\end{tabular} & \\
\hline
\end{tabular}

実験耳に認めるむこれ等は実駼結果より除外する必要が ある。

第 2 節において対昭実験耳 17 亿就き所見を記したが， その中 6 例沉は比較的著明な化膿性內耳炎を認めた：こ れ等症例の大多数は中耳腔汇炎症あり，開空部に之の炎 症か波及し，これより内耳感染を見た事はほざ疑ない。

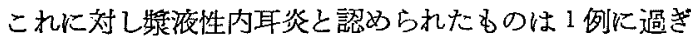
ないしかるにこの成績を第 3 節に打いて記述したぺニ シリン使用実験耳の所見と比較するにかなり著明な美異 が存する. 即ち第 3 節の実唋耳も同じく総数 17 耳であ るが，この中6耳迄は作等かの意味で内耳炎の発生を認 ぬた。しかし乍らその内耳炎は主として限局性䍙液性内 耳炎であつて化膿性内耳炎は1例も認める事ができなか つた.

嘗て高原教授は Shambaugh 教授との共同実験に括 いて，猿に就き内耳開空手術を行つた所，その結果次の ような各種の内耳炎の発生を見る事を知つた。即ら教授 の記述によればその内耳炎を軽症より重症の順に記すれ 
第 10 表 手衏後ペニシリン処置耳所見（生体固定群）

\begin{tabular}{|c|c|c|c|c|c|c|c|c|c|c|c|c|c|c|}
\hline \multirow{2}{*}{\multicolumn{3}{|c|}{ 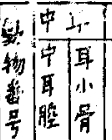 }} & \multicolumn{2}{|c|}{ 前庭 } & \multicolumn{5}{|c|}{ 蜳 4 县 } & \multicolumn{4}{|c|}{ 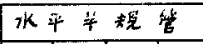 } & \multirow{2}{*}{ 满 } \\
\hline & & & 湟 & 聂 & & 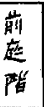 & \begin{tabular}{|l|} 
鼓 \\
䆹 \\
䧿 \\
\end{tabular} & 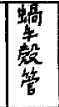 & $\begin{array}{l} \\
n \\
4 \\
4 \\
6 \\
\text { 赛 } \\
\end{array}$ & \begin{tabular}{|l|} 
珤 \\
足 \\
堡 \\
\end{tabular} & 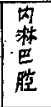 & $\begin{array}{l}\text { 复 } \\
\text { 撫 }\end{array}$ & $\begin{array}{l}\text { 開 } \\
\text { 空 } \\
\text { 部 }\end{array}$ & \\
\hline 5 & & & & & & & 焉褰 & & & & & & $\begin{array}{l}7 \\
\text { 明 }\end{array}$ & \\
\hline$\hat{\hat{\theta}}$ & & 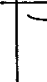 & & & & & 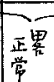 & & & & & & $\begin{array}{l}\text { 不 } \\
\text { 明 }\end{array}$ & \\
\hline 9 & 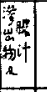 & 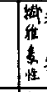 & & & & & 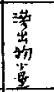 & & & 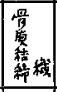 & 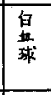 & \begin{tabular}{|l} 
\\
部 \\
保 \\
化 \\
\end{tabular} & $\begin{array}{l}\text { 骨 } \\
\text { 霓 } \\
\text { 等 }\end{array}$ & 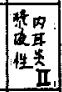 \\
\hline 18 & & & & & & & 覃 & & & & & & $\begin{array}{l}\text { 不 } \\
\text { 明 }\end{array}$ & \\
\hline 22 & 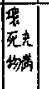 & & & & & & 焉 & & & & & & $\begin{array}{l}\text { 不 } \\
\text { 明 }\end{array}$ & \\
\hline 25 & & & & & & & 管 & & & 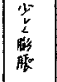 & & \begin{tabular}{|l|}
$\frac{1}{3}$ \\
\\
\end{tabular} & $\begin{array}{l}\text { 不 } \\
\text { 明 }\end{array}$ & \\
\hline 31 & 滰 & & 变 & & & & $\begin{array}{l}\text { 出 } \\
\text { 昷 }\end{array}$ & 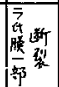 & 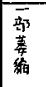 & $\begin{array}{l}\text { 语 } \\
\text { 出 } \\
\text { 物 }\end{array}$ & & $\begin{array}{l}\text { 坅' } \\
\text { 化 }\end{array}$ & $\begin{array}{l}\text { 不 } \\
\text { 明 }\end{array}$ & 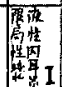 \\
\hline 33 & 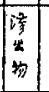 & 部 & $i$ & & & 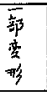 & 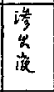 & & 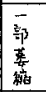 & \begin{tabular}{|c|} 
渗 \\
出 \\
物
\end{tabular} & & & $\begin{array}{l}2 \\
\text { 明 }\end{array}$ & 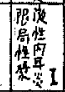 \\
\hline 35 & $\begin{array}{l}\text { 核 } \\
\text { 出 } \\
\text { 物 }\end{array}$ & & & & & & 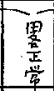 & & & & & & 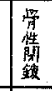 & \\
\hline 37 & & & & & & & & & 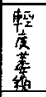 & & & 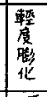 & $\begin{array}{l}\text { 不 } \\
\text { 明 }\end{array}$ & \\
\hline 38 & & & & & & & 搴 & & & & & & $\begin{array}{l}\text { 不 } \\
\text { 明 }\end{array}$ & \\
\hline
\end{tabular}

ば次のようになる。

A. Sterile serous labyrinthitis localized to fenestra Minimal .................................. I

B. Sterile diffuse serous labyrinthitis

Mild ............................................ II

C. Diffuse purulent labyrinthitis …….......

今この重症度分類と実験耳所見との関係を記す机ば次 のようである。

$$
\begin{aligned}
& \text { I ……......No.11, 31, } 33 \\
& \text { II …......... No.9, } 29 \\
& \text { III............ No.6, 23, } 34 \\
& \text { IV ……...... No.30 } \\
& \text { T …........ No.4, 16, 21, 25, } 26
\end{aligned}
$$

\begin{tabular}{|c|c|c|c|c|c|c|c|c|c|c|c|c|c|c|}
\hline 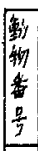 & 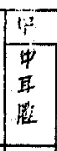 & $\begin{array}{l}\text { 年 } \\
\text { 年 } \\
\text { 骨 } \\
\end{array}$ & 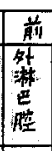 & 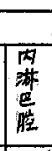 & 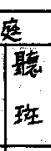 & \begin{tabular}{|l|} 
媀 \\
煎 \\
階
\end{tabular} & 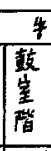 & 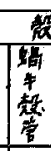 & 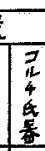 & 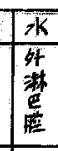 & 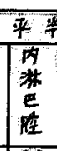 & 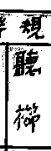 & 陶 & \\
\hline 16 & \begin{tabular}{|l|} 
膘 \\
if
\end{tabular} & & $\begin{array}{l}=5 \\
4 \\
4 \\
\text { 场 }\end{array}$ & & 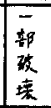 & \begin{tabular}{|l|} 
㕲 \\
垡
\end{tabular} & 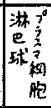 & 童 & 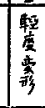 & 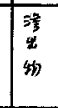 & 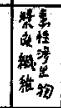 & & 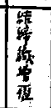 & \\
\hline 7 & 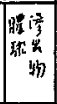 & 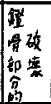 & \begin{tabular}{|l|} 
谣 \\
物 \\
\end{tabular} & & 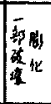 & & & 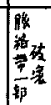 & 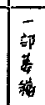 & 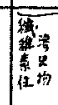 & 繁 & & 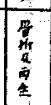 & \\
\hline 1 & 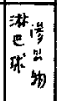 & & & & 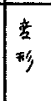 & & & 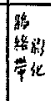 & & 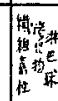 & 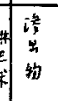 & $\begin{array}{l}\frac{1}{i_{p}} \\
4 \\
4 k\end{array}$ & 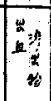 & \\
\hline 17 & 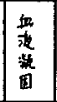 & 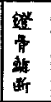 & & & & & & \begin{tabular}{|l|} 
\\
\\
\end{tabular} & $\begin{array}{l}\text { 基 } \\
\text { 始 }\end{array}$ & 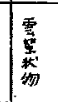 & & \begin{tabular}{|l} 
㬶 \\
th
\end{tabular} & 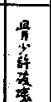 & \\
\hline 23 & $\begin{array}{l}\text { 簿 } \\
\text { it }\end{array}$ & & 加 & & & 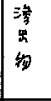 & 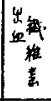 & 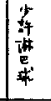 & & 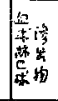 & & 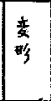 & $\begin{array}{l}7 \\
\text { 的 } \\
\end{array}$ & \\
\hline 29 & 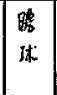 & & 変 & & & \begin{tabular}{|l|} 
整 \\
列
\end{tabular} & & 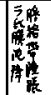 & 破 & 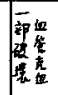 & 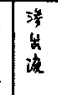 & & $\begin{array}{l}7 \\
\text { 明 }\end{array}$ & \\
\hline
\end{tabular}

よつて今この分類を基礎とし，私のペニシリン使用実

\begin{tabular}{|c|c|c|c|c|}
\hline 高原教授分制 & ペニシリン使用群 & 対 & 照 & 群 \\
\hline I & $\mid 3$ (No.11, 31, 33) & & & \\
\hline II & $2(\mathrm{No} .9,29)$ & & & \\
\hline III & $2(\mathrm{No} .6,23)$ & \multirow{3}{*}{\multicolumn{3}{|c|}{$\begin{array}{l}1 \text { (No.34) } \\
1 \text { (No.30) } \\
5 \text { (No.4.16, 21, 24, 26) }\end{array}$}} \\
\hline IV & & & & \\
\hline V & & & & \\
\hline
\end{tabular}

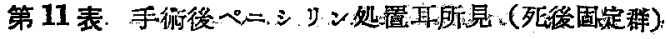

験耳及び対照実験耳にお特ける所見と例数との関係を見る に次のようである.

即ちこの所見よりぺニシリン使用は術後性内耳炎をよ り軽微に済まし得るであるうことが推察せられる。

\section{第 5 章 全編の粉括並び考按}

以上私は実験目的，方洗，所見を夫々章を別つて記述 した・本章においては夫等成續を総括して考按する。

私の本研究に括ける主目的はすでに記した如く果して ペニシリンは開空術後内耳炎を防禦し得るや否や汇あつ た. しかるに40匹の家香を用いこれに私の方法により 内耳開空術を施したところ，第 3 章に記した如く個々の 動物にあつてはその手術操作に多少軽重の差があつた。 しかし乍らこれをぺニシリン処置群及び無処置群の 2 群

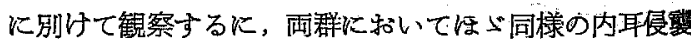
であつた・しかるにその後の生体反応を観察するにぺニ シリン使用群比あつては無使用群よりる症候的に内耳病 変の出現は軽微であつた.しかるに更にこれ等動物行就 
き術後 1 カ月の経過基準とし，その内耳の病理組織学

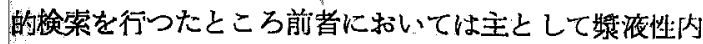
耳咨が認められたに就し，後者にあっては主として化䑚 性内耳炎が認められた。

よって今改めて手術後に叔ける生体反応と内耳病理組 織学的所見との相関関保をベニシッン使用群及び対瞧群: に別けて検討して見るに，次の如くである。

今開空手術時における内耳刺激症状を手術俧及び直媵

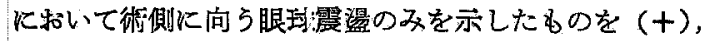

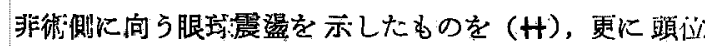
变化，身体迴枟その他の身体平衝障碍を示したものを （卅）とし手術後経過に出いてこれ等症状が増悪乃至出 現したものを手術後経過不良とし，更に病理組織学的に

第 12 表 生体反応並びに內耳润理組織学的所 見の相関々你

\begin{tabular}{|c|c|c|c|c|c|c|c|}
\hline \multicolumn{4}{|c|}{ ペニシリン使用群 } & \multicolumn{4}{|c|}{ 扩 照实 匼 群 } \\
\hline $\begin{array}{l}\text { 動 } \\
\text { 物 } \\
\text { 番 } \\
\text { 号 } \\
\end{array}$ & 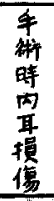 & 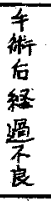 & 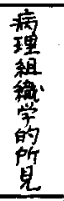 & $\begin{array}{l}\text { 動 } \\
\text { 物 } \\
\text { 番 } \\
\text { 号 } \\
\end{array}$ & 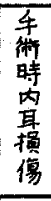 & 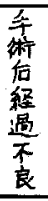 & 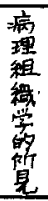 \\
\hline 1 & + & $t$ & 欠 & 3 & $t$ & & \\
\hline 2 & + & & 久 & 4 & \# & + & $H$ \\
\hline 5 & $\mathrm{H}$ & + & & 12 & + & & \\
\hline 6 & + & $t$ & + & 13 & $\mathrm{HH}$ & + & \\
\hline 7 & + & & & 14 & + & & $T$ \\
\hline 8 & $t$ & & & 15 & $t$ & & K \\
\hline 9 & W & + & $t$ & 16 & +4 & + & $\pi$ \\
\hline 10 & $t$ & & 欠. & 19 & + & + & \\
\hline 11 & $\#$ & $t$ & + & 20 & + & + & \\
\hline 17 & + & & & 21 & + & + & + \\
\hline 18 & + & & & 24 & \# & + & H \\
\hline 22 & $t$ & & & 26 & + & + & $\#$ \\
\hline 23 & $\#$ & + & + & 27 & + & & 欠 \\
\hline 25 & + & & & 28 & $H$ & + & \\
\hline 29 & $H$ & + & $t$ & 30 & $H$ & + & H \\
\hline 31 & $\#$ & + & + & 32 & + & & \\
\hline 33 & + & + & + & 34 & + & + & + \\
\hline 35 & $t$ & & & 36 & + & $t$ & \\
\hline 37 & $t$ & & & 39 & $t$ & & \\
\hline 38 & $t$ & & & 40 & $t$ & & \\
\hline
\end{tabular}

將液性内耳炎を認めたものを(十)，化膿性内耳炎を認

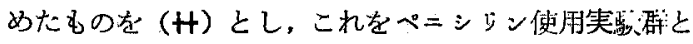
対照実駼群沉別けて1表とすれば第12表のようになる。

今第 12 表によつて按ずるに手術による内耳損傷の軽 重と臨床経過並びに病理組織学的所見の関係矢论表のよ うになる。

\begin{tabular}{|c|c|c|c|c|c|c|}
\hline & حْ & 倾 & 活 & 対 & 照 & 确 \\
\hline $\begin{array}{l}\text { 手㐫程 } \\
\text { 街 } \\
\text { 指 } \\
\text { 時傷㡾 }\end{array}$ & $\begin{array}{l}\text { 洸就 } \\
\text { 洌 } \\
\text { 数 }\end{array}$ & 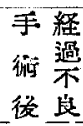 & $\begin{array}{l}\text { 肉所 } \\
\text { 聚見 }\end{array}$ & 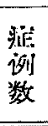 & $\begin{array}{l}\text { 手経 } \\
\text { 甪 } \\
\text { 後是 }\end{array}$ & $\begin{array}{l}\text { 所 } \\
\text { 堅見 }\end{array}$ \\
\hline $\mathrm{H}$ & 3 & 3 & +2 & 4 & 4 & +3 \\
\hline$H$ & 4 & 4 & +4 & 2 & 2 & $H 1$ \\
\hline+ & 13 & 2 & +1 & 14 & 6 & $\begin{array}{l}+1 \\
+12\end{array}$ \\
\hline
\end{tabular}

今本表によつて按ずるにペニシリン使用群及び刘照実

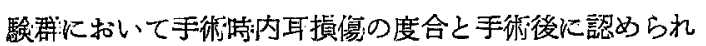
た全身症候並びに病理組䅧学的内耳病変の間にはかなり 密接な関連があるが, 各郡内耳認められた病理組織学 的病変は後者に括いて前者よりも病変が高度である事をる 諗める。

以上の総ての所見を総括し私は次の結論を行い度い。

$$
\text { 結論 }
$$

健康家鬼 40 匹に対し水平半規管化開空術を施行し， 術後その半数に懸濁水性パニシリン G 30 万単位を連日 觔肉注射し，他の半数は無边置として1ヶ月間その生体 反応を観祭し, 更にその後に和いて聴器の病理組織学的 研究を行つた。

その結果手術に上る内耳撌傷の度合は生体.反応に就き 観察した限りペニシリン傎用群と無処置群とはほら゙同様 であつたが，その後の経過において無処置群はべニシり ン使朋群よりも内耳变性の症状をより高度に示した。

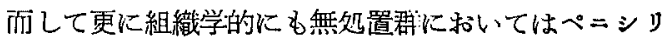
ン使朋群よりもより高度の化膿性内耳炎像を示した。こ の事実は嘗て私が中耿炎 2594 例に就いてぺニシリンの 合併症出現等防の効果を砤めた成績とよく一致する。

以上によつて私は開空術後性内耳炎の発生予防に対し ペニシリンはかなり有效であると考える.

\section{参考文 献}

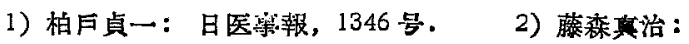

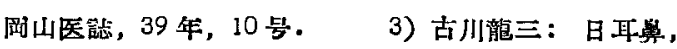

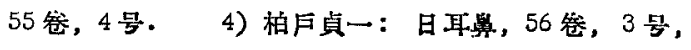

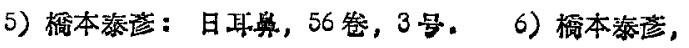




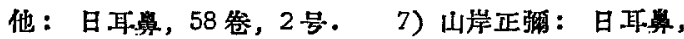

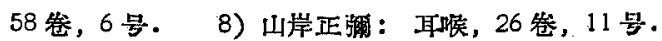
9）來田俊男：日耳尊，59卷，6号. 10）高久亭： 日耳真, 60 卷, 6 号. 11) 猪狝統一：日耳悬，55

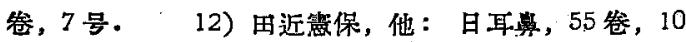

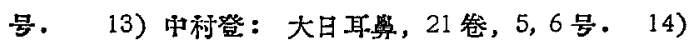
小田大吉, 他：大日耳悬，40卷，5号. 15）徏田

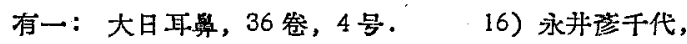
他：北越医誌，47 年，7昂. 17）鳥居惠二：日本 耳盖全書, 第 1 罕, 第 3 册. 18）後藤光治, 他：日

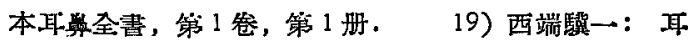

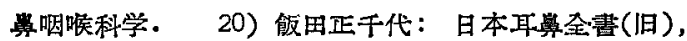

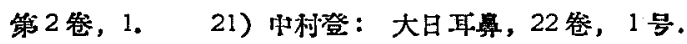

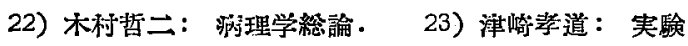
用動物解剖学. 24）社文雄：日本耳鼻全書，第1

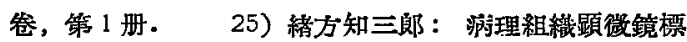
本の作》方. 26) 宮原泫夫：耳悬咽喉科最近の進 步. 27) J. Farrior, Bagby: Arch, Otolaryng. 58, 1, $1953 . \quad 28)$ Schambaugh: Acta. Otolaryng. Supp, 79, 1949. 29) Furstenberg: Annals Otolaryng. 58, 1, 1949. 30) Eggstone, Wolff: $\mathrm{Hi}-$ stopathology of the Ear, Nose and Throat. 1947. 31) L. Haymann: Arch. f. Ohren. Bd. 95, 1914. 32) Hinsberg: Verhandl. d. deutsch Otol. Gesselsch. 1906. 33) Denker-Kahler: Handbuch. d. H.N. Ohren Heilkunde. Bd, 6, 1926.
附，图説 明

第 1 3 図韭手衡耳

第 1 区 動物番是 No.37 螖牛踥。

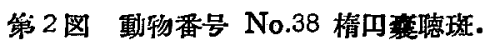

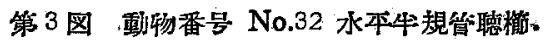

以上はほゔ正常なる內耳を示す。

第 4 6 図手衍後嘒処置耳.

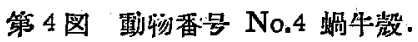

第 5 図 動物番号 No.21 棈円蕧.

第6 图 動物番号 No.21 水平牛規急枨大部.

以上は化眼性內耳桨を示す.

第7〜9図手衍後ペニシリン赺置耳:

第7 図 動物番号 No.23 蛤牛設.

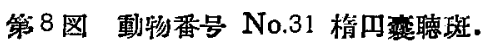

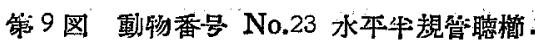

以上は獎源性內耳炎を示す。

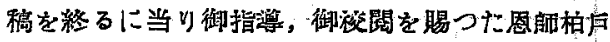
教授に深い謝意を衣すると共に御校閵御教示を賜つ た本学狱理学教室宫村教授，菒理学教室田辺教授に 深謝形します。

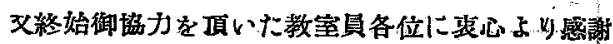
致します。

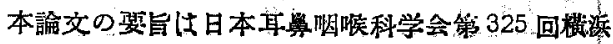
大会, 関東地方会第 28 回大会及び第 57 回総会にお いて発表した。

（原稿到葶 $=$ 昭和 33.10.21 日一急載） 
高見論文附図（I）
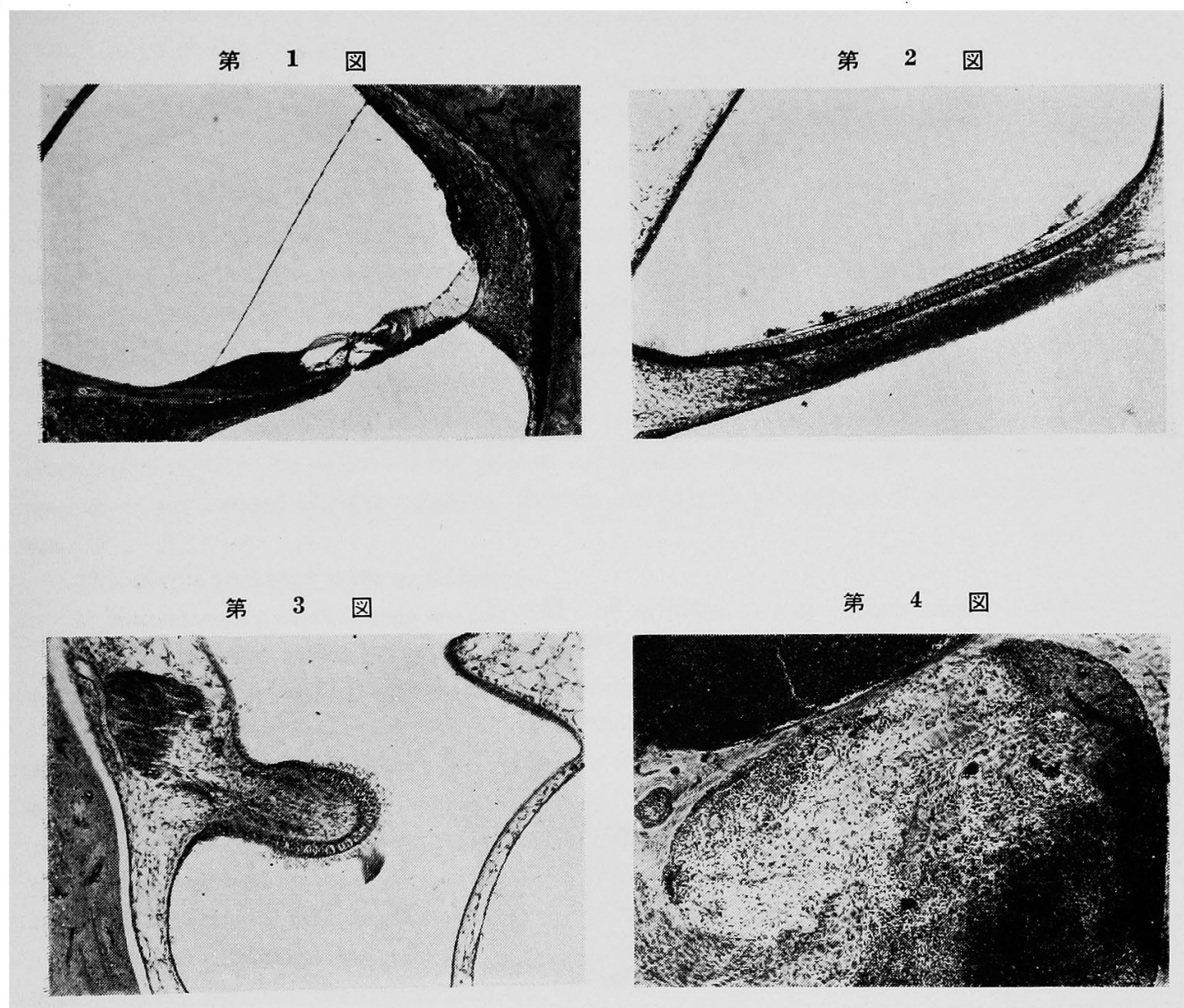

第 4 図
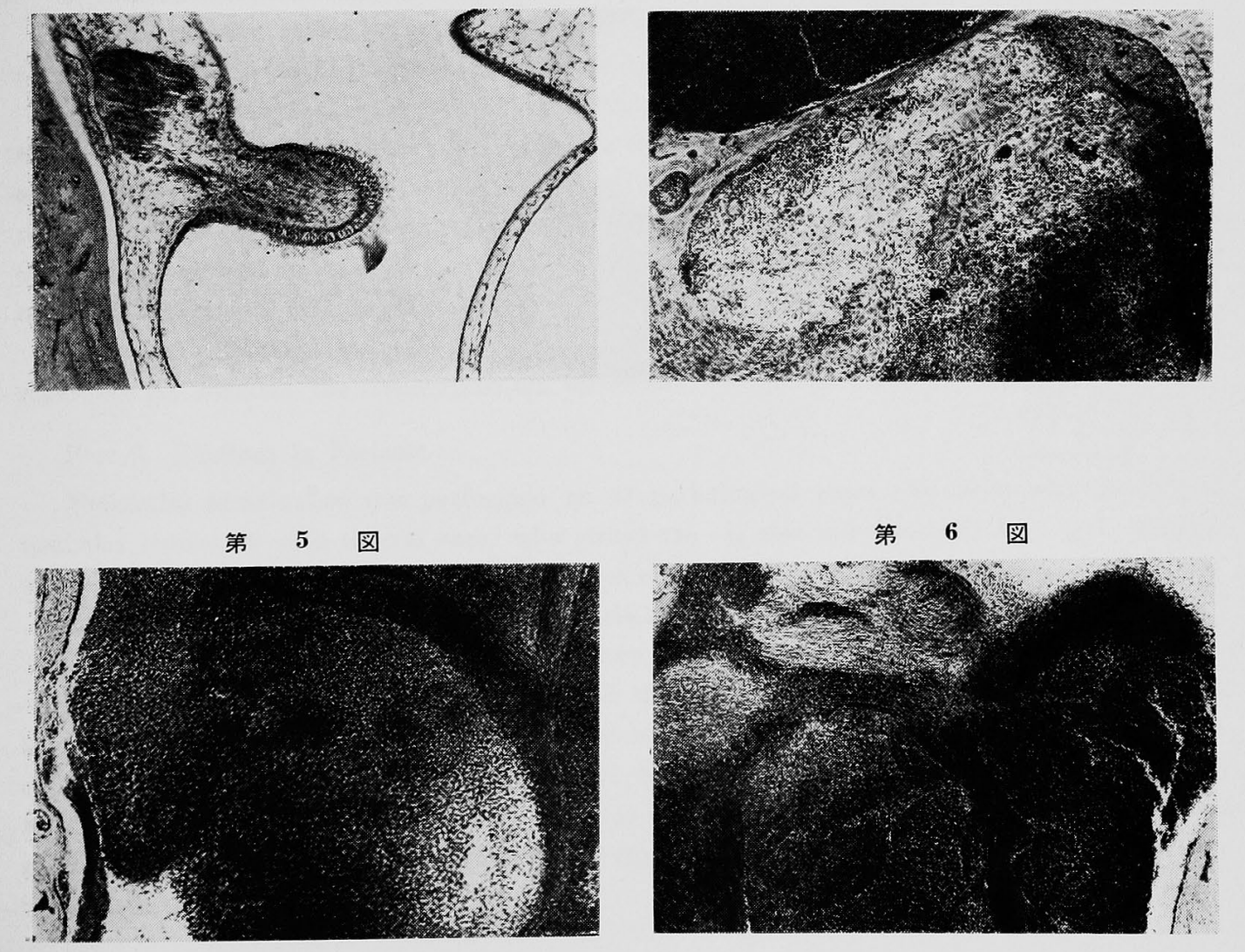


\section{高見論文，附図（II）}

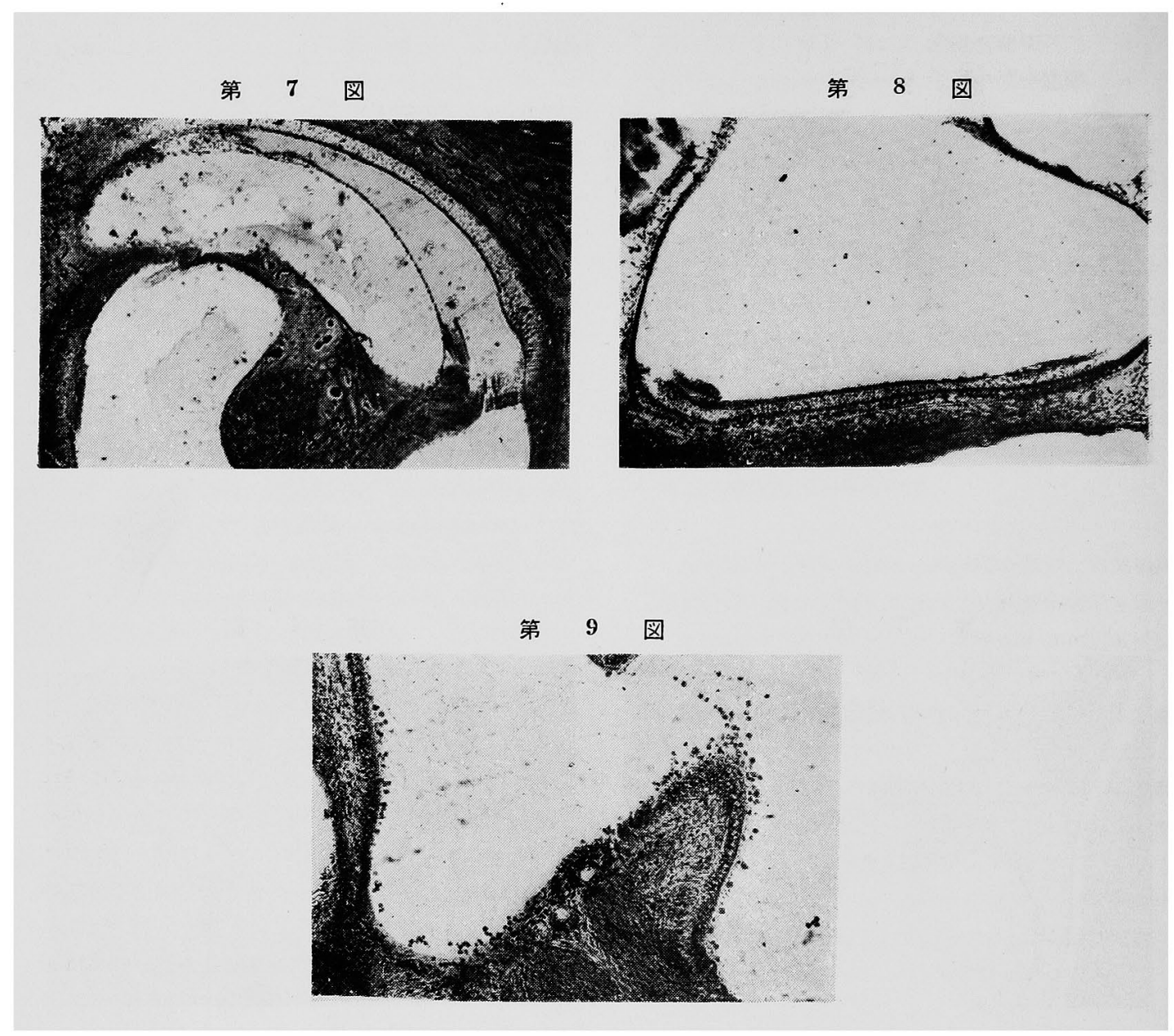

